\title{
КУРГАННЕ ПОХОВАННЯ БРОНЗОВОГО ЧАСУ БІЛЯ СЕЛА ПРОГРЕСІВКА НА ЛІВОМУ БЕРЕЗІ ТИЛІГУЛЬСЬКОГО ЛИМАНУ
}

\author{
Олександр Смирнов 1 , Денис Бондаренко ${ }^{2}$, Леонід Смирнов 3 \\ ${ }_{1}^{1}$ Миколаївський національний університет імені B.О. Сухомлинського \\ e-mail: smyrnovl@ukr.net; ORCID: https://orcid.org/0000-0002-7849-3840 \\ 2 НІАЗ «Ольвія» НАН України \\ e-mail: bondarenkod1987@gmail.com; ORCID: https://orcid.org/0000-0001-6703-6196 \\ 3 Миколаївський національний університет імені B.О. Сухомлинського \\ e-mail: gnom-8@ukr.net; ORCID: https://orcid.org/0000-0002-1955-9117
}

У статті висвітлюються результати рятівних робіт на пошкодженій пам'ятці археології на території Ташинської сільської ради Березанського району Миколаївської області, на північ від села Прогресівка. Розкривається історія археологічних робіт на Березанщині. Дається коротка характеристика поховань та попередня ідентифікація. Розглянуті три поховання, одне з яких - парне. Два поховання відносяться до бабинської історико-культурної спільноти кінця першої - початку другої чверті II тисячоліття до P.Х. а одне, з великою вірогідністю, до рубежу ер (сарматський час).

Ключові слова: курган, поховання, інвентар, бабинська археологічна культура, сармати

У 2019 р. співробітниками Охоронної археологічної служби України Інституту археології Національної академії наук України та Миколаївського національного університету імені В.О.Сухомлинського проведені масштабні археологічні розвідки у північно-західній частині Березанського району Миколаївської області, у зв'язку з плануванням будівництва великої вітроелектростанції вздовж лівого берега Тілігульського лиману.

Територія, яка містить у собі зону будівництва, розташована у Березанському районі на південному заході Миколаївської області, на території Причорноморської низовини, котра являє собою пласку рівнину, розрізану балками та долинами невеличких степових річок Сасик, Царега та Березанка.

Перші археологічні обстеження цієї території відбулися у кінці XIX ст.

В кінці XIX ст. - на початку XX ст. директором Херсонського музею В.I. Гошкевичем обстежено узбережжя лиманів. У ході даних розвідок описані кургани та клади, знайдені на вказаних територіях.

Другий етап археологічних робіт почався з кінця 40-х рр. XX ст. Роботи проводилися співробітниками Одеського археологічного музею та Інституту археології Академії наук УРСР М.С. Сініциним, М.Ф. Болтенко, Е.О. Симонович. Відкриті по берегах лиманів поселення різних археологічних культур у сіл Анатоліївка та Ташино. Тоді ж були початі перші розкопки виявлених об'єктів, у першу чергу, черняхівських могильників. У цей же час вперше були відкриті поселення епохи бронзи. С.I. Капошина та Л.М. Славін проводили розкопки пам'яток археології, які відносяться до античного часу. На початку 1950-х рр. у північній частині району велику кількість поселень відкрив місцевий краєзнавець Л.В.Кондрацький. Пізніше, за його підтримки, ці пам'ятки обстежені Західно-Скіфською степовою експедицією IIMК АН СРСР під ке- 
рівництвом Н.Н. Погребової. На деяких поселеннях проведені невеличкі дослідження, вивчення деяких пам'яток продовжувалося і надалі1.

Третій, наймасштабніший етап почався у 1970-х рр. і закінчився у сер. 1990-х рр. 3 1973 р. периферійні загони Ольвійської експедиції ІААН УРСР під керівництвом А.В. Буракова та С.Б. Буйських проводили поступове дослідження берегів лиманів, розташованих у районі. В результаті була відкрита велика кількість поселень античності та епохи бронзи. Усі виявлені античні об'єкти відносяться до архаїчного, класико-елліністичного та римського періодів².

Що стосується досліджень курганних пам'яток археології, слід зауважити, що деякі з них були пограбовані ще у кінці XIX ст. Пізніше проводилися наукові роботи з їх вивчення.

Масштабні розкопки курганів Березанщини почалися з 1974 р. у зв'язку з будівництвом зрошувальної системи на півдні України й тривали декілька років. Роботи проводилися Інгульською експедицією ІА АН УРСР.

У 1987 р. під час підготовки написання «Зводу пам’яток історії та культури УРСР» співробітники Інституту археології України В.М. Отрешко та С.О. Ліпавський провели першу спробу фронтального обстеження пам'яток археології Березанського району (огляд курганних пам'яток проводив Ю.С. Гребенников). Всього було обстежено та зафіксовано 113 курганів і раніш виявлених поселень.

В 1995 р. співробітниками Миколаївського краєзнавчого музею Ю.С. Гребенниковим, В.Б. Гребенниковим, I.О. Снитко, С.І. Гавриловим проведено друге фронтальне вивчення території району, в ході якого відкрито 15 нових поселень і 152 кургани.

У 2000 р. експедицією НЦ Одеського державного університету під керівництвом Ю.С. Гребенникова досліджений курган біля с. Анатоліївка, в якому виявлено 9 поховань епохи бронзи.

На основі відкритих матеріалів, за роки дослідження на території всього Березанського району, вивчено більше 20 курганів, а у даний час їх на землях району зафіксовано більше 300. Крім цього є відомості про 2 городища, 3 стоянки, більше 90 поселень і 7 грунтових могильників ${ }^{3}$.

У 2012 р. співробітники Інституту археології НАН України проводили огляд територій, де передбачається будівництво вітроелектростанцій, виявлені об'єкти нанесені на карти з урахуванням картографічних прив'язок (рис.1). Нові дослідження, зважаючи на місцевість, призведуть до відкриття ще не виявлених пам'яток археології (курганів, могильників, поселень) ${ }^{4}$. Також протягом червня-серпня 2019 р. були проведені попередні археологічні дослідження на замовлення ФОП Янчук Володимир Петрович.

У жовтні 2011 р. та червні 2013 р. Миколаївська археологічна експедиція дослідила два кургани бронзового часу біля села Тузли у верхів'ї Березанського лиману5. Дослі-

\footnotetext{
1 Гребенников В.Б. Исследования памятников археологии Николаевщины. Николаев: Иллион, 2011. С. 20-28.

2 Крыжицкий С.Д., Буйских С.Б., Отрешко В.М. Античные поселения Нижнего Побужья (археологическая карта). Киев: Наукова думка, 1990.

3 Гребенников В.Б. Исследования памятников археологии Николаевщины... С. 20-28.

4 Бондаренко Д., Смирнов О., Смирнов Л. Археологічні розвідки на території Березанського району Миколаївської області в 2012 р. // Аркасівські читання: матеріали IV Міжнародної наук.практич. конф. (11-12 квітня 2014 р.). Миколаїв: МНУ ім. В.О. Сухомлинського, 2014. С. 10-15.

5 Смирнов О.І., Разумов С.М., Карнаух Є.Г., Смирнов Л.І. Дослідження кургану 2 біля с. Тузли Березанського р-ну Миколаївської обл. // Археологічні дослідження в Україні 2013 р. Київ, 2014. С. 199-200.
} 
джено загалом 17 поховань, які відносяться до культур бронзового часу Півдня України, а саме - ямної культурно-історичної спільноти, інгульської культури катакомбної культурно-історичної спільноти, бабинської культурно-історичної спільнотиб.

Літом 2019 р., під час проведення попередніх археологічних досліджень (наукові археологічні вишукування) у рамках договору № 224-13-19 між ФОП Янчук Володимир Петрович і Державним підприємством «НДЦ ОАСУ ІА НАН України», на території Ташинської сільської ради Березанського району Миколаївської області, було зафіксовано факт порушення чинного законодавства України у сфері охорони культурної й археологічної спадщини: знищення курганної групи.

На курганах виявлено факт масштабного руйнування насипів курганів внаслідок сільськогосподарської діяльності, незважаючи на сервітути та встановлені охоронні зони та державні обмеження. На пам'ятках виявлені людські рештки, рештки людських поховань, поховальних конструкцій і поховального інвентарю (рис.2). У польових умовах керівником Миколаївської археологічної експедиції прийнято рішення провести охоронні дослідження пошкоджених поховань. Роботи проводились протягом одного дня, а саме 5 липня 2019 р. (рис. 3). Головним завданням було дослідити археологічні об’єкти (поховання), зафіксувати поховальні конструкції, положення кістяків і вцілілого інвентарю in situ. Над пошкодженими похованнями був розбитий квадрат, його розміри відповідають плямам грунту, що відрізнялисz від загальної геологічної картини. Квадрат досліджувався по шарам, до моменту виявлення людських решток. Зачистка поховань проводилась за загальноприйнятою методикою фахівцями експедиції.

Висота кургану - 0,40 м, діаметр - 35 м.

Вся площа насипу піддається руйнації шляхом сільськогосподарської діяльності. Після чергової оранки, у південній полі кургану зафіксовано зірвані з місця камені дрібного та середнього буту черепашнику, а також - фрагменти сіроглиняного кубку (?) (рис. 4, 1).

3 метою вивчення частково зруйнованого поховання у центральній частині насипу закладено шурф з широтною орієнтацією розмірами $4 \times 4$ м.

Поховання № 1. Впущене у гумусний насип кургану. Зафіксоване на глибині 0,18 м від вершини кургану. Контури грунтової ями не прослідковуються. Кістяк розміщений у витягнутому на спині положенні, головою на північ. Череп дещо припіднятий у потилиці та розвернутий лицьовою частиною праворуч вгору. Щелепи відкриті. Тулуб дещо розвернуто праворуч. Права рука витягнута вздовж тіла, розташована на дні могили; ліва - розміщена на лівій частині ребер. Ноги - прямі, кістки лівої ноги нижче колінного суглобу - відсутні. На правому плечі похованого зафіксовані фрагменти верхньої частини ліпного горщика. Виходячи з орієнтації поховання, ми можемо припустити, що це $є$ впускне поховання рядового члена сарматського суспільства7 (рис. 5).

Поховання № 2 зафіксовано у центральній частині кургану, на південь від поховання № 1. Поховальна споруда впущена у гумусний насип кургану та, частково, материк (на глибину 0,40 м), фіксується з глибини 0,32 м від вершини насипу. Споруда

\footnotetext{
6 Разумов С.Н., Смирнов А.И., Смирнов Л.И., Карнаух Е.Г. Курганы бронзового века у села Тузлы в верховьях Березанского лимана // Stratum plus. 2015. № 2. С. 329-361.

7 Смирнов О.І Деякі аспекти впускних поховань сарматів у I-II ст. по Р.X. // Науковий вісник Миколаївського державного університету. Вип. 11: Історичні науки. Збірник наукових праць. Миколаїв, 2005. C. 54-61.
} 
являє собою прямокутну яму, орієнтовану по вісі північний схід - південний захід, розмірами 1,54 (Пн.-Сх.-Пд.-Зх.) × 0,87 (Пн.-Зх.-Пд.-Сх.) м. Борти ями по периметру обкладено орфостатно встановленими великими полігональними плитами черепашнику, розмірами 0,29 0,69×0,23 0,52×0,04 0,15 м. Максимальна глибина ями 0,53 м від рівня фіксації каміння. Дно ями - материк (глина жовтого кольору). Поховання зруйноване. На дні ями зафіксовані людські кістки в неанатомічному порядку. Після того, як яма була заповнена грунтом на 0,17 м, в її центральній частині були орфостатно встановлені дві плити черепашнику, які утворили стіну, орієнтовану у напрямку південний-захід - північний схід, яка розділяє яму на дві приблизно рівні частини. В оточенні поховальної конструкції зафіксовані масивні плити черепашнику, розмірами 0,16 0,73×0,14 0,71×0,05 0,12 м, які, вірогідно, в давнину перекривали споруду. Кам'яна споруда та можлива прив'язка сіроглиняного кубку з ручкою, який був знайдений на поверхні порушеної пам'ятки, дають нам можливість віднести поховання до пізнього етапу бабинської культури ${ }^{8}$ (рис. 6; 4, 2).

Поховання № 3 зафіксовано на схід від поховання № 2 у катакомбі. Склепіння не збереглося. Поховальна камера орієнтована по вісі північний захід - південний схід. Вхідна яма, вірогідно, розташовувалася у західній частині споруди. Катакомба мала близьку до овальної в плані форми, розмірами по дну 1,90 (Пн.-Зх. -Пд.-Сх.) × 1,42 (Пн.-Сх.-Пд.-Зх.) м, глибина від рівня вершини кургану - 1,46 м. У заповненні поховальної камери зустрічається дрібний і середній бут черепашнику

У центральній частині катакомби на дні зафіксовано парне поховання. Північний кістяк розташований у напівскорченому на лівому боці положенні головою на північний схід. Тулуб прямий. Ліва рука знаходиться під тілом, права - витягнута вздовж тулуба. Ноги зігнуті у колінних суглобах під гострим кутом і піджаті до тіла під тупим кутом.

Південний кістяк розташований у скорченому на лівому боці положенні, головою на північний захід. Череп небіжчика розміщений біля правого плеча північного поховання. Хребет вигнуто у скорченому положенні, руки зігнуті в ліктях, кисті розташовані навпроти обличчя. Ноги повністю зігнуті у колінах і піджаті до тулуба майже під прямим кутом.

Біля обличчя північного скелету, навпроти дальньої стіни поховальної камери, на її дні зафіксовано ліпний горщик, встановлений на дно. Цей об'єкт також, як і поховання № 2, виходячи з типологічної характеристики, відноситься до бабинської історико-культурної спільності(рис. 7; рис. 4, 2).

На жаль, констатуємо наступне: дане дослідження фрагментарне. Носило охоронний і рятівний характер. Повністю пам'ятка залишилася недосліджена (сподіваємось на правоохоронні ограни та можливість повністю дослідити курган), виявлено три поховання. Поховання № 1 - впускне, сарматського часу та поховання № 2 i № 3 відносяться до бабинської історико-культурної спільноти, скоріш за все поховання № 3 - до класичного часу, а поховання № 2 - до пізнього варіанту дніпродністровського степового локального варіанту дніпро-прутської бабинської культури. Стратиграфію кургану прослідкувати не вдалося, що і не дозволяє нам відокремити основне поховання (скоріш за все, у недослідженій частині пам'ятки) та прослідкувати етапи насипів і підсипок. У подальшому планується зробити антрополо-

\footnotetext{
8 Кетрару Н.А., Синика В.С., Разумов С.Н., Тельнов Н.П. Дубоссарские курганы. Тирасполь: Stratum plus, 2014. $238 \mathrm{c}$.
} 
гічний аналіз та аналіз на С14, а повна обробка речового комплексу, із залученням фахівців з даної проблематики, планується у найближчий час 9.

\section{REFERENCES}

Bondarenko, D., Smyrnov, 0. \& Smyrnov, L. (2014). Arkheolohichni rozvidky na terytorii Berezanskoho raionu Mykolaivskoi oblasti v 2012 r. [Archaeological exploration in the Berezansky district of Mykolaiv region in 2012]. Abstracts of Papers: Arkasivski chytannia: IV Mizhnarodna naukovo-praktychna konferentsiia (11-12 kvitnia 2014r.), (pp.10-15). Mykolaiv: MNU imeni V.O. Sukhomlynskoho [in Ukrainian].

Grebennikov, V.B. (2011). Issledovaniia pamiatnikov arkheologii Nikolaevshchiny [Research of monuments of archeology of Nikolaiev region]. Nikolaev: Illion [in Russian].

Ketraru, N.A., Sinika, V.S., Razumov, S.N. \& Telnov, N.P. (2014). Dubossarskie kurgany [Dubossary mounds]. Tiraspol: Stratum plus [in Russian].

Kryzhytskii, S.D., Buiskikh, S.B. \& Otreshko, V.M. (1990). Antichnye poseleniia Nizhnego Pobuzhia (arkheologicheskaia karta) [Antique settlements of Lower Pobuzhie (archaeological map)]. Kiev: Naukova dumka [in Russian].

Razumov, S.N. Smyrnov, A.I. Smyrnov, L.I. \& Karnaukh, E.G. (2015). Kurgany bronzovogo veka u sela Tuzly v verkhoviakh Berezanskogo limana [Bronze Age barrows near the village of Tuzla in the upper reaches of the Berezansky estuary]. Stratum plus, 2, 329-361 [in Russian].

Smyrnov, O.I. (2005). Deiaki aspekty vpusknykh pokhovan sarmativ u I-II st. po R.Kh. [Some aspects of the inlet burials of Sarmatians in the I-II centuries A.D.]. Naukovyi visnyk Mykolaivskoho derzhavnoho universytetu, (Vol. 11, pp. 54-61). Mykolaiv [in Ukrainian].

Smyrnov, O.I., Razumov, S.M., Karnaukh, Ye.H. \& Smyrnov, L.I. (2014). Doslidzhennia kurhanu 2 bilia s. Tuzly Berezanskoho raionu Mykolaivskoi oblasti [Study of Mound 2 near the village Tuzla, Berezansky district, Mykolaiv region]. Arkheolohichni doslidzhennia v Ukraini 2013 r. Kyiv, 199-200 [in Ukrainian].

\section{Oleksandr Smyrnov}

(Mykolaiv National University named after V. Sukhomlinsky, Mykolaiv, Ukraine)

ORCID: https://orcid.org/0000-0002-7849-3840

\section{Denys Bondarenko}

(Olbia National Historical and Archaeological Reserve of the National Academy of Sciences of Ukraine, village Parutyno, Mykolaiv region, Ukraine)

ORCID: https://orcid.org/0000-0001-6703-6196

\section{Leonid Smyrnov}

(Mykolaiv National University named after V. Sukhomlinsky, Mykolaiv, Ukraine)

ORCID: https://orcid.org/0000-0002-1955-9117

\section{Bronze Age Burial Mound near Prohresivka Village on the Left Bank of the Tylihul Estuary}

The results of rescue work at the damaged archaeology site (barrow) on the territory of Tashyne village council, Berezanka District, Mykolaiv Region located to the north of Prohresivka village are highlighted in the paper. The damage was found during the frontal and local archaeological survey carried out in the frame of Tashyne village council expert examination regarding the presence or absence of archaeological sites in the area of the wind farm and related facilities installation. The history of archaeological works in Berezanka area is analyzed from the first archaeological surveys at the end of the 19th century, works during

\footnotetext{
${ }_{9}^{9}$ Автори висловлюють подяку за допомогу в роботі над матеріалом К.В. Горбенку, С.М. Разумову та В.С. Сініці.
} 
the $20^{\text {th }}$ century with their stages to the description of the latest studies at the beginning of the $21^{\text {st }}$ century.

The studied area is very rich in archaeological sites in a wide chronological range. Basically, these are burial complexes (barrows) from the Late Neolithic to the Early Iron Age and the settlements of the Bronze Age. There are many archaeological objects of ancient times (settlements and burial grounds) belonging to the Olbia rural district (choras) dated from the $5^{\text {th }}$ century BCE to the beginning of the CE.

A brief description of the studied burials and their preliminary identification is given. Three burials, one of which is a double one, are described in detail.

Two burials belong to Babyne historical and cultural circle dated to the end of the 1st quarter - beginning of the $2^{\text {nd }}$ quarter of the $2^{\text {nd }}$ millennium BCE. The double burial is in a small catacomb with a niche, and a separate one is in a stone box (made of large and medium limestone slabs). The inventory and the location of the skeletons in the graves are given.

One burial, taking into account the typology of the skeleton position and the location of the entrance grave relative to the probable center of the mound and the main burial of an earlier historical epoch, is more likely may be dated to the beginning of CE (Sarmatian time, Middle Sarmatian archaeological culture).

Taking into account the achieved results the further work at the site will enable: to complete the study of the burial complex; to conduct a comprehensive analysis of anthropological, zoological and material evidence; to set the bounds of the site; to identify the main burial; to separate the primary mound from the later layers (additions) of the mound; to introduce new data on the presence of the nomads of the Bronze Age and the Early Iron Age in the North Black Sea region; to separate or fill the contact areas of different local population groups of one cultural and historical community; to study the migration and trade and economic relations of the region in the specified historical period.

Keywords: barrow, burial, inventory, Babyne archaeological culture, Sarmatians 


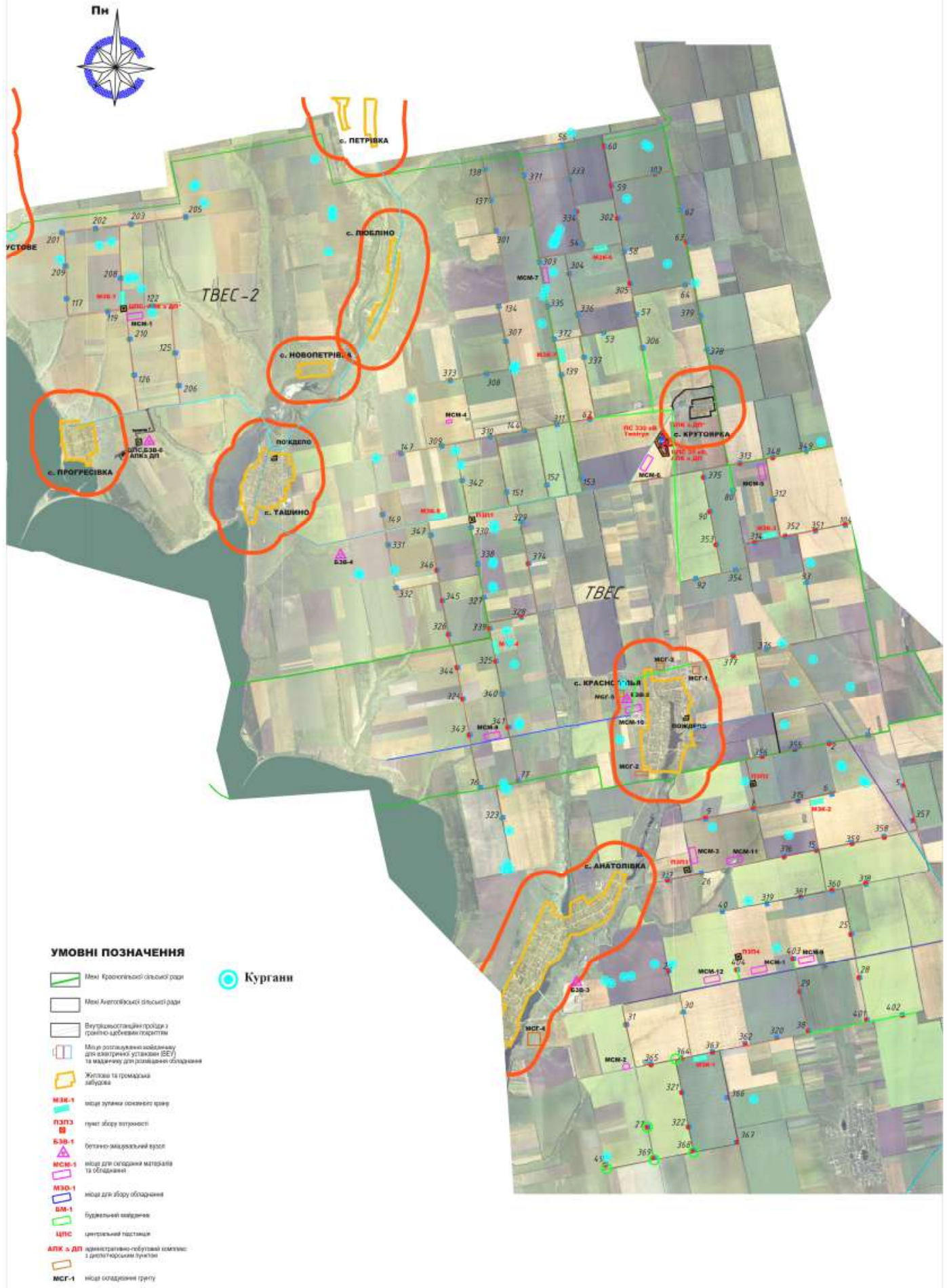

Рис. 1. Насиченість пам'яток археології в зоні розташування ВEC 

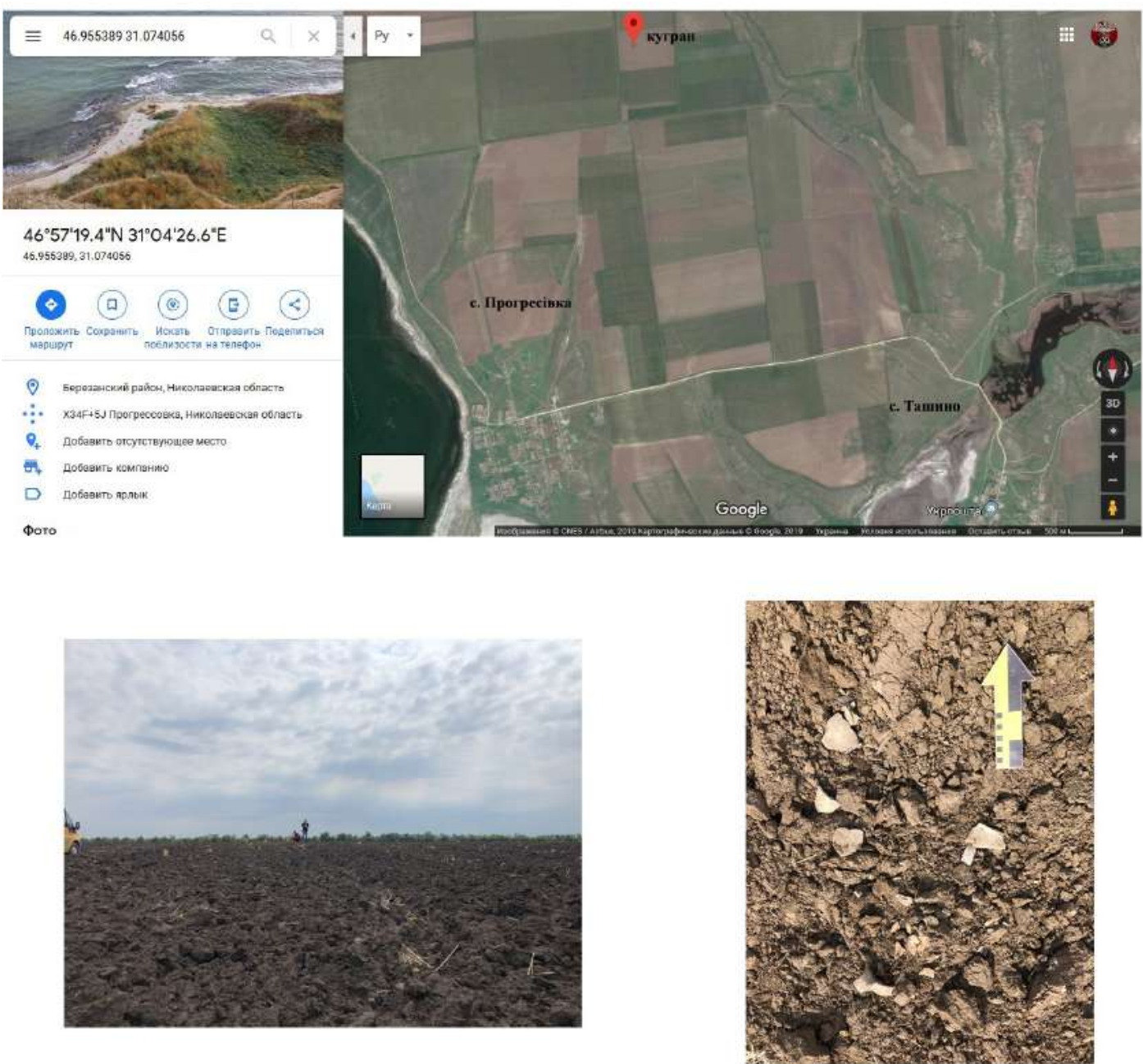

Рис. 2. Місце розташування об’єкту археології та факту руйнування кургану та поховань 

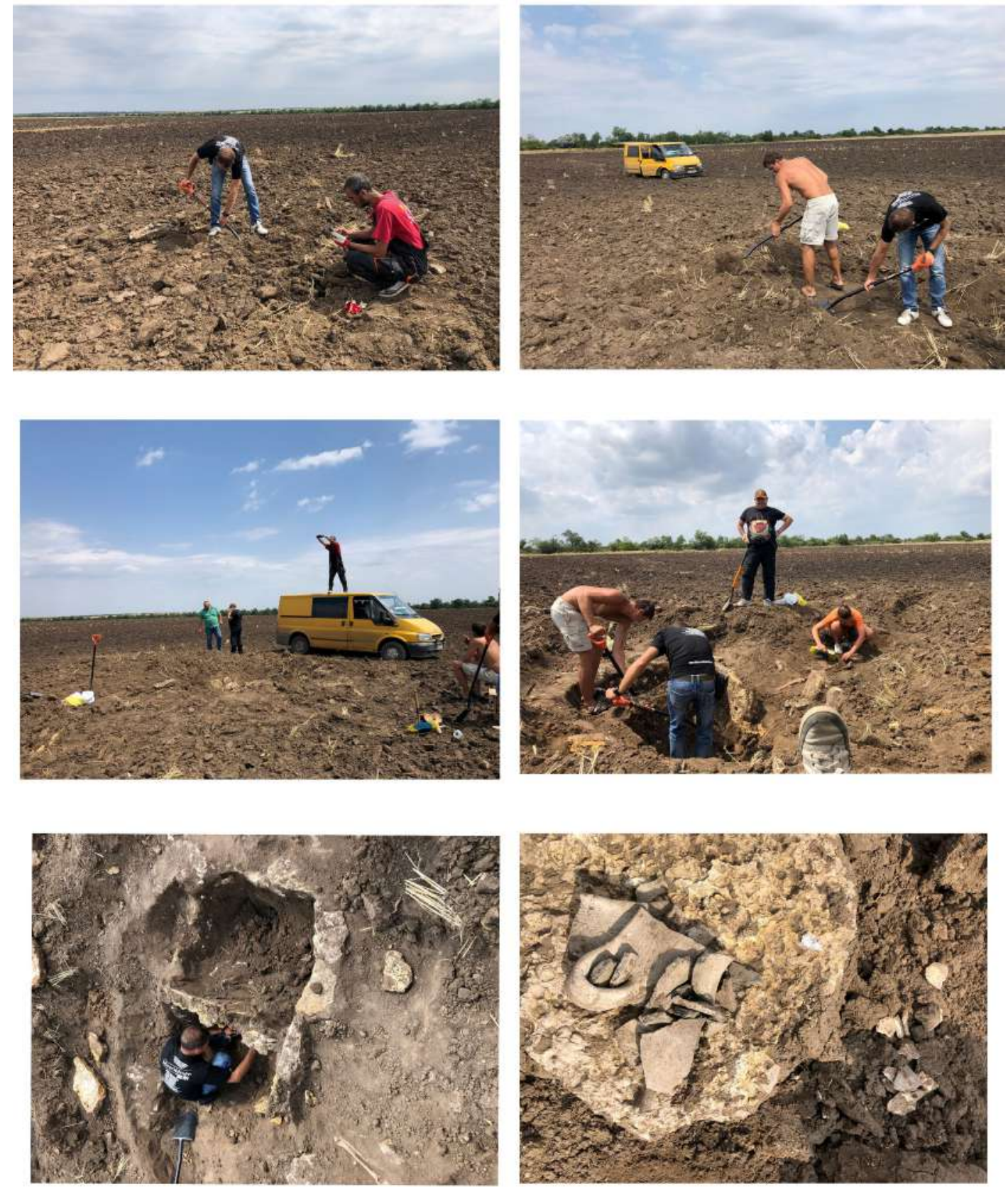

Рис. 3. Робочі моменти 

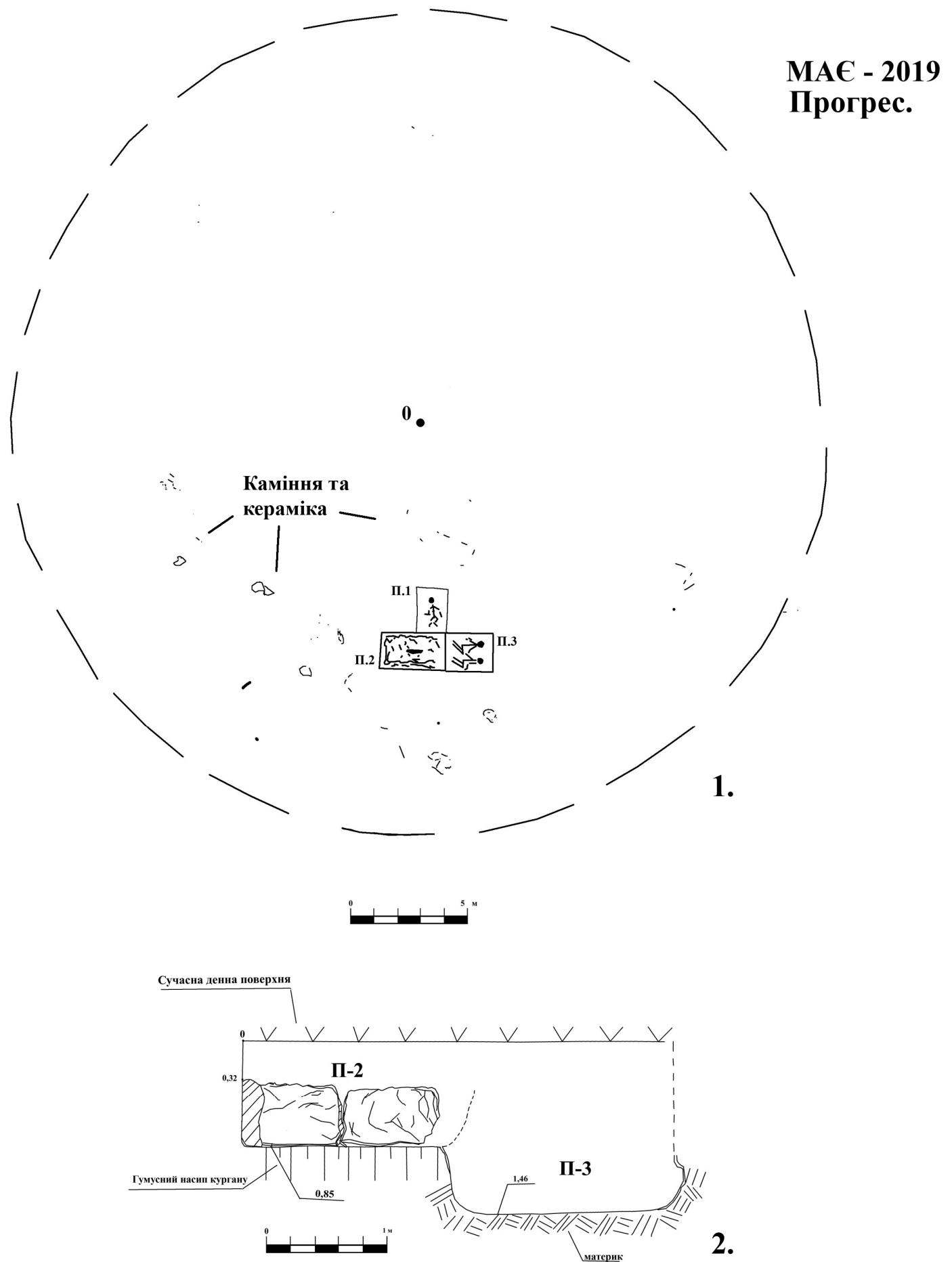

Рис. 4. 1. Ймовірна реконструкція кургану; 2. Стратиграфія П2 та П3 

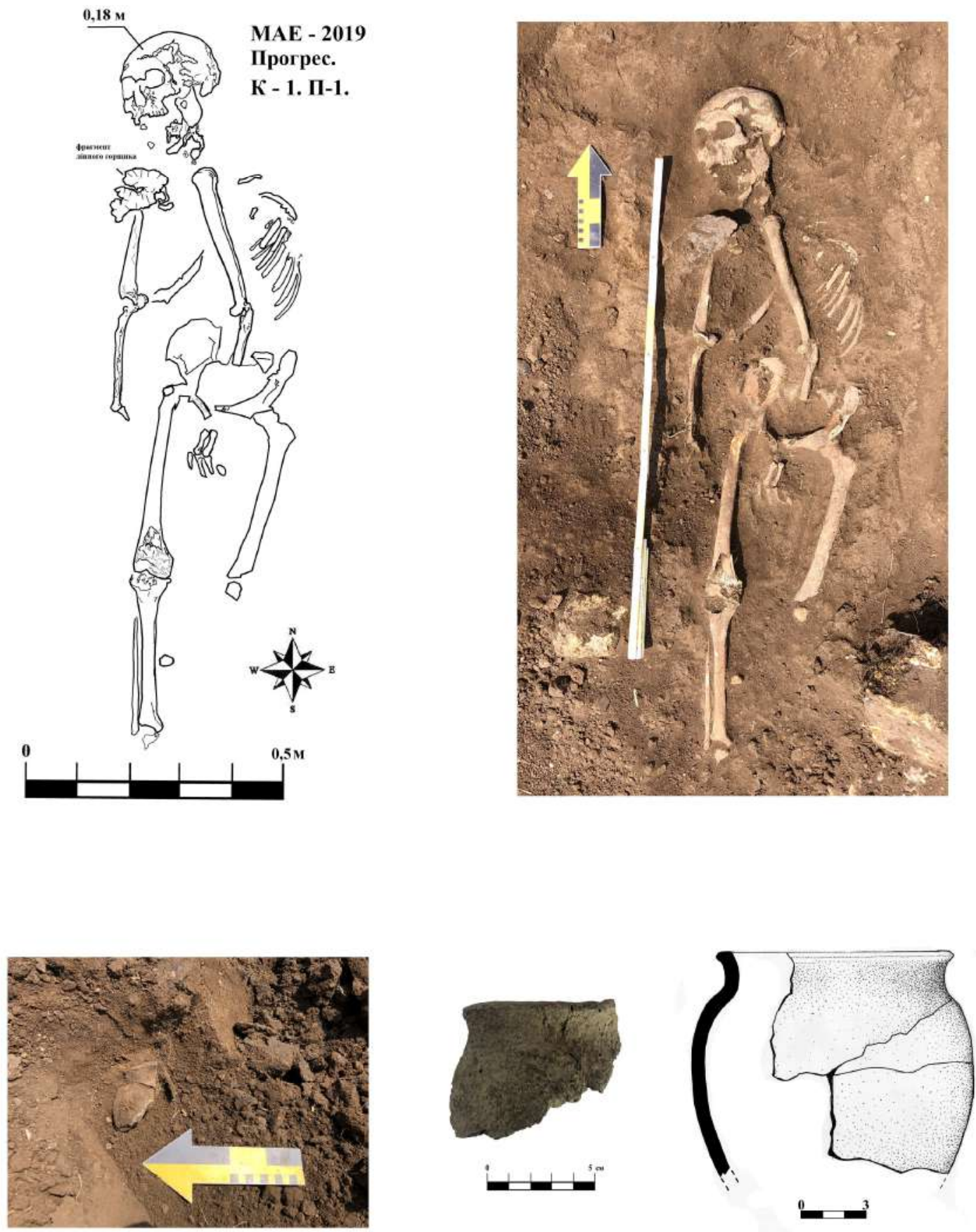

Рис. 5. Поховання № 1 та його інвентар 

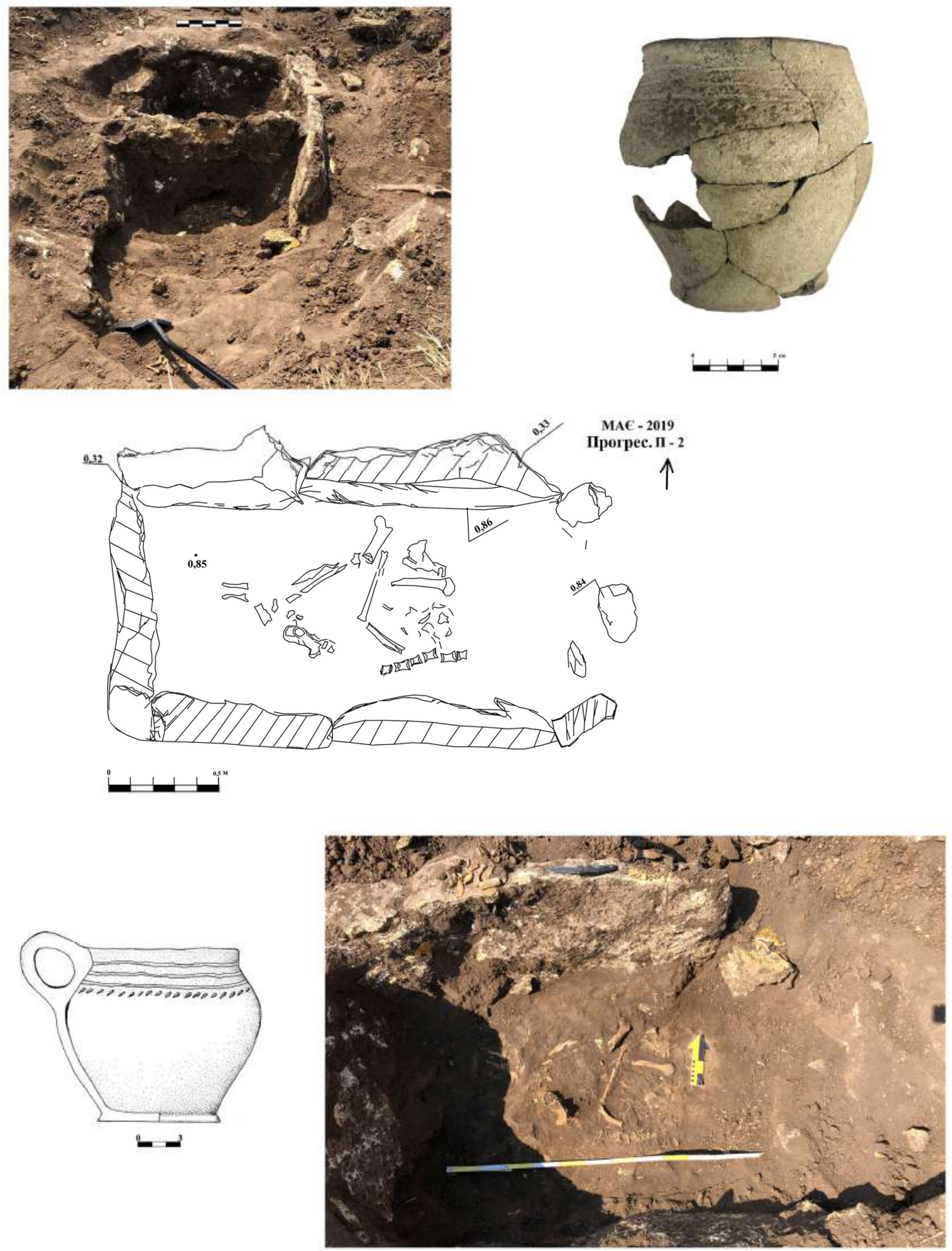

Рис. 6. Поховання № 2 та його інвентар 

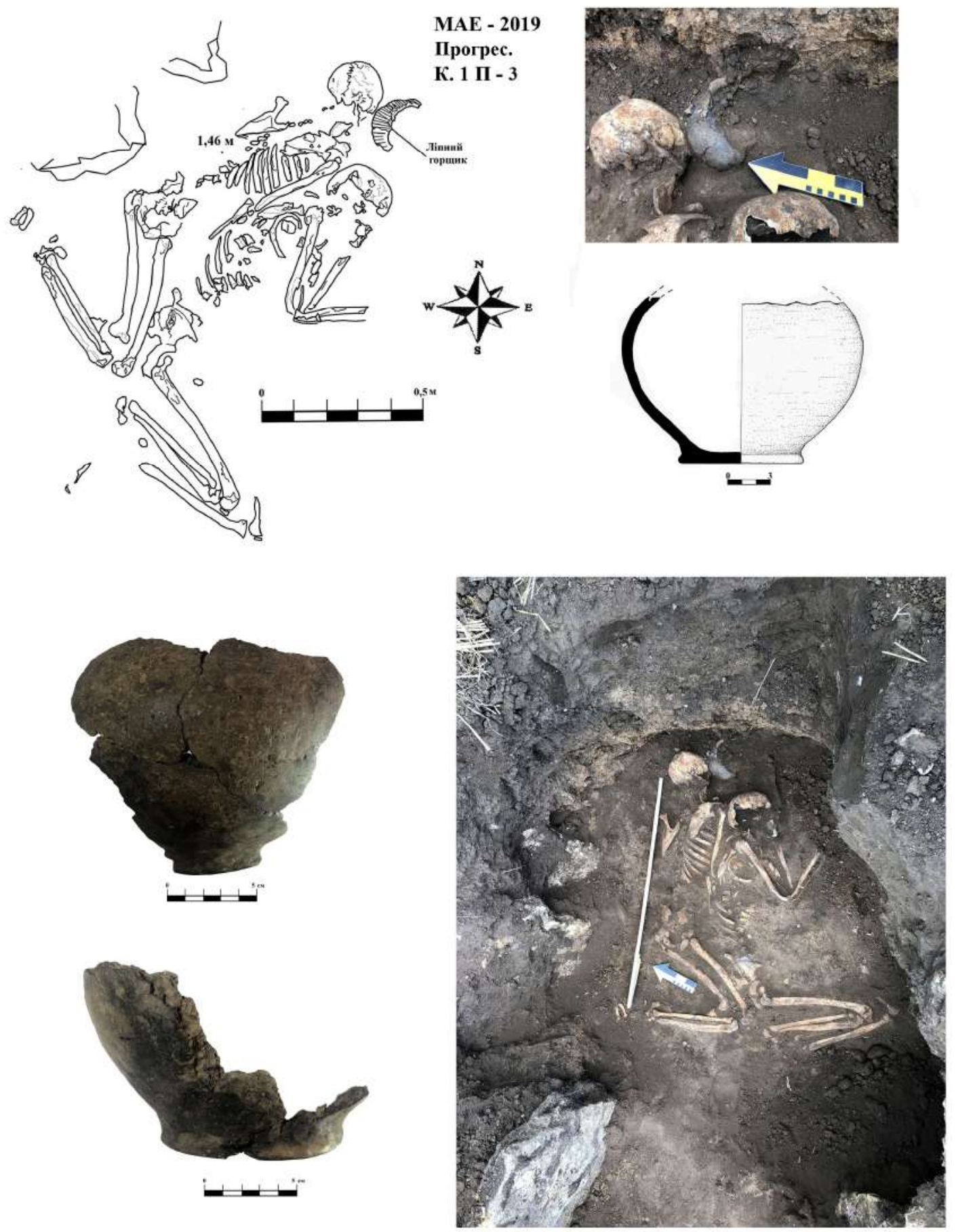

Рис. 7. Поховання № 3 та його інвентар 